\title{
Consequences of Circadian Disruption in Shift Workers on Chrononutrition and their Psychosocial Well-Being
}

\author{
Nor Amira Syahira Mohd Azmi ${ }^{1}{ }^{(\mathbb{D}}$, Norsham Juliana ${ }^{1, *} \mathbb{( D}$, Nur Islami Mohd Fahmi Teng ${ }^{2}(\mathbb{D}$, \\ Sahar Azmani ${ }^{1}$, Srijit Das ${ }^{3}$ and Nadia Effendy ${ }^{1}$ \\ 1 Faculty of Medicine and Health Sciences, Universiti Sains Islam Malaysia, Pandan Indah 55100, Malaysia; \\ amirasyahira188@gmail.com (N.A.S.M.A.); drazmanisahar@usim.edu.my (S.A.); nadia@usim.edu.my (N.E.) \\ 2 Faculty of Health Sciences, Universiti Teknologi MARA, Bandar Puncak Alam 42300, Malaysia; \\ nurislami@uitm.edu.my \\ 3 Department of Anatomy, Universiti Kebangsaan Malaysia Medical Centre, Cheras 56000, Malaysia; \\ srijit@ukm.edu.my \\ * Correspondence: njuliana@usim.edu.my; Tel.: +(06)-797-8623
}

Received: 19 February 2020; Accepted: 8 March 2020; Published: 19 March 2020

\begin{abstract}
The workers and employees in various institutions are subjected to different shifts and work schedules. The employees work not only at daytime but also during odd hours at night. The biological clock of an individual is often altered during night shifts. This affects the psychosocial well-being and circadian nutritional intake of the worker. Disturbance in circadian rhythm results in the development of metabolic disorders such as hypertension, dyslipidemia, dysglycemia, and abdominal obesity. In the present review, we discuss the nature of shift work, sleep/wake cycle of an individual, chrononutrition, dietary habits, and meal changes with regard to timing and frequency, related to shift work. We also discuss the relationship between nutritional intake and psychosocial well-being among shift workers. The review may be beneficial for prevention of metabolic disorders and maintaining sound psychological condition in shift workers.
\end{abstract}

Keywords: workers; shift; biological clock; circadian rhythm; diet; psychosocial

\section{Introduction}

Throughout the world, twenty-four-hour services are a thriving part of the community. In order to meet the continuous demand of the urban world, crucial services are established by several industries and business establishments, which operate on $24 \mathrm{~h}$ basis. It is a necessity for many industries, including healthcare, transport, mining, and aviation, to have staff available for $24 \mathrm{~h}$ a day. These industries demand workers to perform significant tasks over a $24 \mathrm{~h}$ period [1]. Hence, it causes workers to routinely work on the basis of shift schedules [2]. Working in shifts consequently leads to an alteration in the biological clock. This affects the psychosocial well-being and circadian nutritional intake. Chrononutrition is a new area of study that emphasizes the interaction between nutritional intake and time of eating [3].

The worrying fact is that disruption of circadian rhythm often leads to increased risk of metabolic syndrome. Health problems such as hypertension, dyslipidemia, dysglycemia, and abdominal obesity occurring secondary to insulin resistance are commonly seen [4]. One of the reasons for the health consequences of shift work may be that food becomes a $24 \mathrm{~h}$ activity in a $24 \mathrm{~h}$ culture [5]. While those on a more conventional daytime work schedule are most likely to eat three meals every $24 \mathrm{~h}$, with food consumed during daytime [6,7], shift work usually contributes to altered eating patterns with food consumed across the $24 \mathrm{~h}$ period, including those at night [5,7]. Shift workers regularly 
experience circadian misalignment, which occurs when the fast/feeding times are desynchronized with the temporal pattern established by the central circadian clock [8]. In relation to this, the changes in the intake of food especially among shift workers are known to influence many elements of cognitive performance, emotional state, and wakefulness [9]. For example, the cognitive-behavioral consequences of food intake restrictions for the short term are associated with lack of energy supply, whereas the long-term effect involves lack of supply of essential nutrients [10]. The intake of nutrients, thus, plays a decisive role in the regulation of the nervous system and behavior [11].

It is important to highlight the concern of nutritional intake and psychosocial dilemma among shift workers in order to design and promote suitable lifestyle practices for the population. Hence, in the present review, we aimed to explore the impact of circadian disruption in individuals working in shifts and the effect on their chrononutrition and psychosocial well-being.

\section{Materials and Methods}

This was a narrative review. A literature search for relevant articles was conducted in October 2019 using databases such as Google Scholar, PubMed, and Scopus. The studies were identified on the basis of information available in the title and abstract. Relevant search terms included "circadian rhythm", "biological clock", "shift work", "psychological", "nutrition", "diet", "shift work and circadian rhythm", "shift work and dietary habit", "shift work and psychological". We found 110 articles on the basis of the above search approach. All the studies were limited to the publications in the English language, and we took into account all publications from 2000 until 2019.

\section{Results and Discussion}

The results and discussion section outlines the nature of shift work, sleep/wake cycle, chrononutrition, daytime meal, late-night meal, dietary habit and meal changes due to shift work, altered sleep/wake cycle and nutritional intake, psycho-social well-being and nature of work, as well as the relationship of nutritional intake and psychosocial well-being among shift workers.

\subsection{Nature of Shift Work}

There are different working hours according to each country, e.g., approximately $35 \mathrm{~h}$ per week in France [12], $37 \mathrm{~h}$ per week in Denmark [13], and more than $40 \mathrm{~h}$ per week in United States (US). In accord with the US, the Association of Southeast Asian Nations (ASEAN) countries, which include Brunei, Cambodia, Indonesia, Laos, Malaysia, Myanmar, Philippines, Singapore, Thailand, and Vietnam, also have more than $40 \mathrm{~h}$ of working hours per week [12,14]. Shift work is characterized by working during daytime hours, which comprises fluctuating or rotating patterns among night, early morning, and evening schedules [15].

The magnitude of shift work is regularly growing in the modernized environment as a result of an ascending financial system and enhanced global transportation [16]. Night shift is characterized by the time of the work interval between midnight and five o'clock in the morning, and the shift lasts for at least seven consecutive hours. Shift work allows continuous operation of certain industries by establishing a rotation work schedule among employees [17]. Shift work schedules vary greatly with regard to timing and duration for every shift, and the speed of shift rotation. However, it is widely accepted that prolonged exposure to a shift work schedule is related to increased health complications compared with those working at normal daytime hours (Table 1) [18]. According to World Health Organization (WHO), the definition of "health" is a state of complete physical, emotional, as well as social wellness, and not only mere absence of illness or ailment [19].

An earlier study by Atkinson et al. (2008) reported numerous adverse effects on health outcomes related to shift work, including increased risk of sleep alteration and fatigue, cardiovascular diseases, and obesity [20]. Physiologically, sleep disturbance among shift workers is a result of desynchronization between light-dark phase, sleepiness, and intake of food [8]. This, in turn, gives impact to their physical and psychological wellness and also negatively affects the performance at the work place [21]. 
Figure 1 illustrates the effect of circadian rhythm disruption on different body systems that include cardiovascular, gastrointestinal, and central nervous system [22-28].

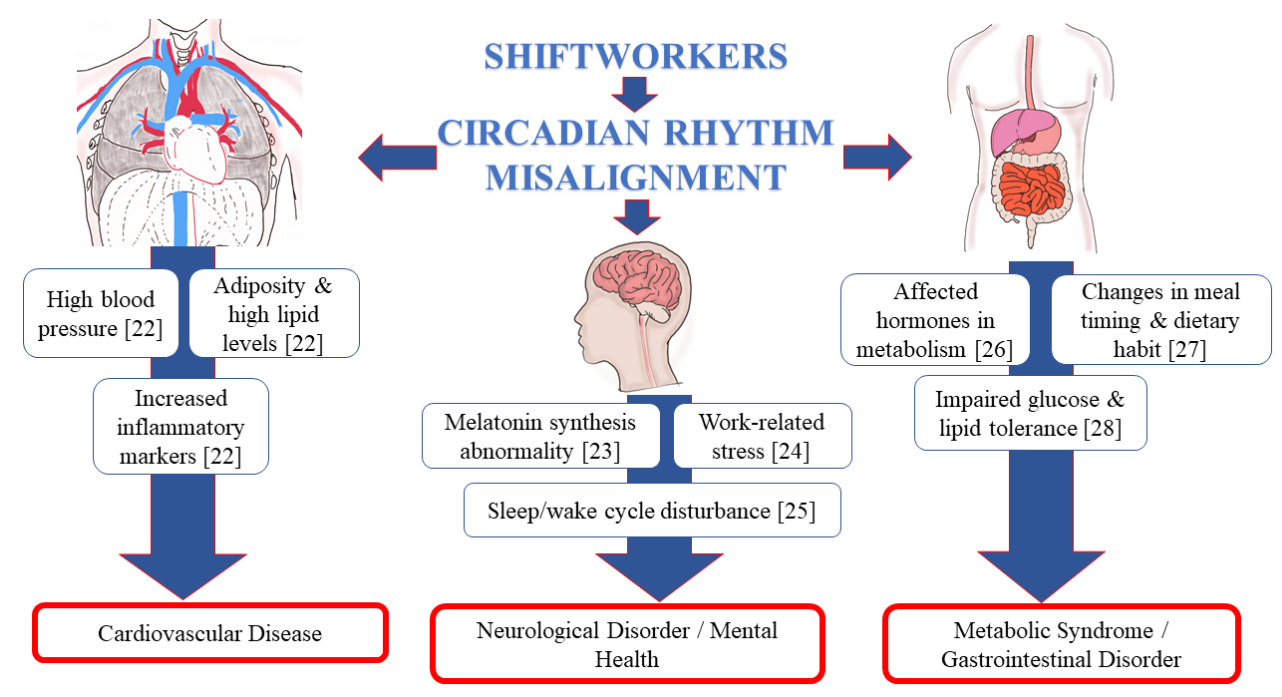

Figure 1. Schematic diagram on the effect of circadian rhythm disruption on different body systems.

\subsection{Sleep/Wake Cycle (24-h Circadian)}

Humans are mainly active or awake during the day and inactive or asleep at night. The cycle is in synchrony with the light and dark cycle during day and night. Nevertheless, this has evolved remarkably since the 19th century with the artificial light discovery that directed to the opening of the first power plant, which consequently led to the availability of a continuous and reliable point of supply for the electrical power through day and night. The advancement of modern technology provides the artificial light to brighten the night. Hence, this condition is capable to alter the humans to be active at night during the normal sleeping time. When the normal synchronization of the sleep/wake and light/dark cycles are disrupted, humans override the circadian control of the sleep/wake cycle, and that, in turn, promotes internal desynchronization between circadian rhythm and sleep [25,29].

The circadian system coordinates physiology and behaviors towards the environment in a way that the body works as a finely harmonized clock. The suprachiasmatic nucleus (SCN) of the hypothalamus acts as the master clock, synchronizing $24 \mathrm{~h}$ rhythms in physiological behavior in the body, inclusive of other brain regions and peripheral tissues. When aligned accordingly to the environment, the clock stimulates sleep and related anabolic functions at night, such as immune function and hormone release, and wakefulness and its associated catabolic functions during the day, i.e., food intake and metabolism, physical activity [30,31]. In addition, the endogenous melatonin rhythm that is controlled by the SCN clock often demarcates the internal biological day and night. For instance, in humans, there is a high level of melatonin secretion during the biological night, and low melatonin level occurs during the biological day [23,32]. Moreover, similar clock oscillators to the SCN clock were identified in peripheral tissues such as gastrointestinal tract liver, muscle, or adipose tissue [33]. It has been shown that consuming food which sometimes contradicts our circadian rhythms can entrain rhythms in peripheral tissues, like liver [34], resulting in long-term health issues [35]. Desynchronization caused by feeding or alternative mechanisms of entrainment in a population of shift workers can lead to defective use of substrates, resulting in the disruption of metabolic pathways, thereby leading to intramyocellular accumulation of lipids and insulin resistance [8].

The natural periodic condition of rest for the mind and body is by having adequate sleep, and the average duration of sleep for an adult is 7 to $9 \mathrm{~h}$ per day, as per recommendation by The National Sleep Foundation $[36,37]$. The individuals may act and think slow, and have tendencies to create more errors if they do not get sufficient sleep. Consequently, sleep deprivation can lead to susceptibility 
of having typical viral infection, diabetes, obesity, heart disorder, as well as depression [38]. This is demonstrated in Figure 1, i.e., the effect of circadian disruption on important systems in the body.

Reduced sleep quality influences significant changes in the eating behavior among shift workers by boosting their appetite late night, thereby leading to obesity [39-43]. While there is evidence that leptin and ghrelin are altered with sleep constraint, thereby raising appetite at night, there is also evidence that factors other than hunger drive shift workers to eat throughout the night shift. For instance, due to the time available and break availability, there is social pressure to eat with colleagues, as a strategy to stay alert, avoiding gastric upset as well as stress eating [44]. It was also emphasized by Waterhouse et al. (2003) that some of the significant factors of shift workers eating at night are due to habits, time pressure, and social factors [6]. Besides, colleagues also act as significant role models, where they copy positive and negative attitudes from one another [45]. The timing and meal quality are limited by job requirements in the workplace and the social, domestic, and rest requirements outside the workplace [5].

For humans, early morning exposure to bright light helps earlier circadian rhythm advancement progress. Conversely, early night exposure to bright light delays these rhythms [46]. The light exposure pattern can be designed to reset the central circadian pacemaker quickly to earlier or later stages [47]. The shift workers' sleep schedule is erratic and always abruptly displaced at abnormal circadian phases [46]. The majority of the night shift workers have different degrees of circadian adaptation to their schedules of work [48]. Individuals vary widely in their degree of tolerance towards shifting work because of the intensity of circadian and sleep-wake disruptions [49]. Furthermore, it was reported that the circadian pacemaker's full adaptation to night shift work would only take place in a minority of workers, even if they work on a fixed night shift schedule [50]. Hence, it is difficult for the adaptation to circadian rhythm to happen among shift workers in view of the rotating shift schedule which is not fixed.

In a shift work simulation study, subjects that develop sleep deprivation tend to choose low nutritional value snacks together with sweetened beverages during odd times of the day [39]. Morris et al. $(2015,2016)$ confirmed that circadian rhythm misalignment stimulates metabolic dysfunction that eventually leads to weight gain [51,52]. The biological clock performs the function to fix to an energy restrain mode after late night. Therefore, intake of energy-dense food at night promotes rapid fat deposition. In relation to this, meal consumption at night also demonstrates impairment of lipid and glucose tolerance in view of hormonal disturbance in the metabolism $[28,53,54]$. The health impact with shift work is represented in the form of a table (Table 1).

Table 1. Impact of shift work on health of individuals.

\begin{tabular}{|c|c|c|c|c|}
\hline Study \& Country & Method & $\begin{array}{l}\text { Sample } \\
\text { Size }(n)\end{array}$ & $\begin{array}{l}\text { Disease Related to } \\
\text { Shift Works }\end{array}$ & Description on the Disease \\
\hline $\begin{array}{l}\text { Nikpour et al. [55] } \\
\text { (Iran) }\end{array}$ & $\begin{array}{l}\text { Cross-sectional } \\
\text { study }\end{array}$ & 209 & $\begin{array}{l}\text { Metabolic } \\
\text { syndrome }\end{array}$ & $\begin{array}{l}\text { Diagnostic criteria: simultaneously met three } \\
\text { out of five criteria: } \\
\text { (1) Hypertension, } \mathrm{BP}>130 / 85 \mathrm{mmHg} \text {; } \\
\text { (2) High serum TG level }>150 \mathrm{mg} / \mathrm{dl} \text {; } \\
\text { (3) High FBS }>110 \mathrm{mg} / \mathrm{dl} \text {; } \\
\text { (4) Low serum HDL level }<50 \mathrm{mg} / \mathrm{dl} \text {; } \\
\text { (5) Abdominal obesity, WC }>88 \mathrm{~cm}\end{array}$ \\
\hline $\begin{array}{l}\text { Thomas et al. [22] } \\
\text { (United Kingdom) }\end{array}$ & $\begin{array}{l}\text { Large } \\
\text { population-based } \\
\text { cohort study }\end{array}$ & 7839 & $\begin{array}{l}\text { Cardiovascular } \\
\text { disease }\end{array}$ & $\begin{array}{l}\text { Risk factors of cardiovascular disease such as } \\
\text { adiposity, blood pressure, blood lipids, blood } \\
\text { glucose, and level of inflammatory factors }\end{array}$ \\
\hline $\begin{array}{l}\text { Koh et al. [56] } \\
\quad(\text { Korea })\end{array}$ & $\begin{array}{l}\text { Cross-sectional } \\
\text { study }\end{array}$ & 203 & $\begin{array}{l}\text { Gastrointestinal } \\
\text { disorders }\end{array}$ & $\begin{array}{l}\text { Diseases include irritable bowel syndrome, } \\
\text { functional dyspepsia }\end{array}$ \\
\hline $\begin{array}{l}\text { Ferri et al. [24] } \\
\text { (Italy) }\end{array}$ & $\begin{array}{l}\text { Cross-sectional } \\
\text { study }\end{array}$ & 213 & $\begin{array}{l}\text { Psychological } \\
\text { disorders }\end{array}$ & $\begin{array}{l}\text { Job dissatisfaction, poor sleep quantity and } \\
\text { quality, chronic fatigue, psychological stress }\end{array}$ \\
\hline
\end{tabular}

Note: BP, blood pressure; TG, triglyceride; FBS, fasting blood sugar; HDL, high-density lipoprotein; WC, waist circumference. 


\subsection{Chrononutrition}

Chrononutrition is a term that describes food consumption in consideration of the meal timing. Normally, three elements of time are acknowledged, i.e., (1) inconsistency (irregular routine of eating), (2) frequency (the number of daily meals), and (3) clock time (definite time of intake) [58]. The most obvious timings of intake in discussing eating behavior are the breakfast, lunch, tea, dinner, and supper or late-night eating. Previous studies highlighted that changes in the intake for breakfast and supper have a significant impact on the body weight and health [59].

The gastrointestinal tract is lined with enteroendocrine cells that provide endless supply of different hormones based on cues from ingested foods [60]. Subsequently, signals are sent via gut-brain axis to the brain. Energy balance and homeostasis are achieved only by symphonious response of peripheral metabolism in the body. The favorable process of metabolism demands well-regulated eating habits as hormonal regulation occurs at a specific period of time to ensure the optimal process to take place, not too rapid and not too slow. Interestingly, the entire timely process works efficiently based on specific types of macronutrients [61].

The first meal of the day regulates the determination of peripheral clocks' circadian rhythm, meanwhile, the last meal of the day brings about the process of lipogenesis and accumulation of adipose tissues [62]. Previous studies pointed out that activation of lipolysis was prolonged and lipogenesis process increased among the breakfast skippers $[63,64]$. There was evidence that night shift workers skipped their breakfast due to the nature of shift that ended early in the morning. It was also reported that the workers preferred to sleep after the night shift [65]. On the other hand, another study showed that post night shift workers often consume a heavy breakfast, followed by sleep [66]. Another example is that of the shift workers who might eat breakfast at the end of a night shift before driving home, while few might eat at home before their daytime sleep, and also others who eat with their family when they get home after a night shift.

It has been understood that since breakfast usually follows the longest fasting period during the $24 \mathrm{~h}$ daily cycle, the omission of breakfast could significantly alter metabolism and disrupt the function of gastrointestinal tract. This subsequently leads to reduced availability of nutrients to the brain and likely adverse behavioral outcomes [67]. The effect is similar in those who work normal working hours, but study has shown that shift workers are more susceptible to breakfast skipping. For instance, a study by Axelsson et al. (2004) found that the shift workers might be inclined to skip breakfast so as to allow more sleeping time [49].

However, another important issue that needs to be emphasized when targeting the time of the first meal of the day is the setting of insulin secretion. As insulin fluctuation is closely dependent on meal timing, eating the first meal of the day too early with an insufficient restraining food intake period may result in a weak resetting effect of insulin secretion. All these mechanisms contribute to significant implications on weight gain, appetite, as well as glucose and lipid metabolism [35,62,68]. Morris et al. (2016) also proposed that irrespective of the behavioral cycle consequences, glucose tolerance was lower in the biological evening than in the morning. Thus, it indicated that one of the important factors to consider in shift workers is the internal circadian time of food intake [52].

\subsection{Daytime Meal}

Eating breakfast is considered to have good effect on the quality of diet throughout the day [69]. Specifically, breakfast is being described as a fundamental aspect in daily nutritional necessity, which is also partly responsible for nutritional quality and energy intake [70]. The definition of breakfast is the earliest eating event that takes place in a day, within the timing of two hours of waking up from sleep, and approximately before 10:00 am [71]. Based on previous studies, it is reported that diseases of dyslipidemia [72], hypertension [73], diabetes mellitus [72], coronary heart disease [74], and weight gain [75] are associated with skipping of breakfast. However, the timing of breakfast among shift workers is subjected to the timing of last energy intake on the previous day, in order to ensure a sufficient fasting period for the body to reset its metabolism. 
Barr et al. (2013) examined the association between breakfast, nutritional intake, and nutrient adequacy among Canadian adults in order to specify the type of nutrients to be consumed. Breakfast consumers, especially ready-to-eat cereal breakfast consumers, had positively higher fiber intake as well as several vitamins and minerals compared with breakfast skippers [76]. Besides, a survey of the Bogalusa Heart Study ( $n=504 ; 58 \%$ women; $70 \%$ white; age of 19 to 28 years old) reported $74 \%$ of breakfast skippers did not achieve two-thirds of the Recommended Dietary Allowance for vitamins and minerals, compared with $41 \%$ of the breakfast consumers [77]. Furthermore, consumption of protein during breakfast causes better initial and sustaining feeling of fullness, greater satiety, and low concentration of the appetite-regulating hormone ghrelin [78-80]. Almoosawi et al. (2013) recommended that a long-term protective effect against metabolic syndrome can be obtained by increasing the intake of carbohydrate in the morning [81].

\subsection{Late-Night Meal}

Shift workers were found to have nibbling behavior during their night shifts, mainly high-carbohydrate food. The nocturnal feeding imitates night eating syndrome (NES) effects that were first described by Stunkard et al. in 1955 [82]. Multiple studies by St-Onge et al. (2017), Berg et al. (2009), and Cleator et al. (2012) reported that late-night meal was associated with obesity and cardio-metabolic health [83-85]. There were no reports on associated similar psychological outcome among patients suffering from NES and shift workers who had late-night eating habits.

Compared with high-fat diets, consumption of foods rich in carbohydrate at night creates a greater increment of sleepiness level and a decrement in mental performance, contrary to the physical act $[86,87]$. Meanwhile, there was an association between protein intake and diminished feeling of hunger, increased satiety, and reduced caloric intake, in comparison with other macronutrient intakes [88]. Protein-rich meals promote higher satiety and alertness due to the thermogenic effect [89]. Thus, it is recommended for the shift workers to consume high-protein diet at night and reduce the intake of food that is rich in carbohydrate in order to have a productive night shift work.

\subsection{Dietary Habit and Meal Changes due to Shift Works}

According to the systematic review and meta-analyses by Bonham et al. (2016), it was reported that the energy intake of shift workers lasting $24 \mathrm{~h}$ did not vary from that of fixed day workers [90]. It was suggested that eating meals specifically at the wrong time of the $24 \mathrm{~h}$ cycle was a key contributor to the increased risk of metabolic disturbances in shift workers [91]. Hence, it was obviously shown that meal timing and chrononutrition was important to consider.

A study conducted by Gifkins et al. (2018) among nurses working in shifts found that there was increased food craving, caffeine consumption, and snacking behaviors throughout the night shifts as well as the inability to consume enough fluids at work. The experienced nurses described more about meal skipping at work and relation with a tremendous workload as well as consumption of alcohol as the approach to rest from shift work [27]. Likewise, it was reported among the mine workers who worked in rotating shift duties that they had difficulty in following typical patterns to consume meals [92]. Meanwhile, for other jobs like flight attendants and long-distance truck drivers, the choices about the meal timing and availability of food were restricted in view of fluctuating work schedules [93,94].

Shift work was also strongly related to abnormal eating habits among nurses according to a study done by Wong et al. (2010) in a major acute hospital in Hong Kong. The Dutch Eating Behavior Questionnaire (DEBQ) scores from the participants for components of abnormal emotional, external, and restraint were $66.4 \%, 61.4 \%$, and $64.0 \%$, respectively. The results also showed that the nurses having four or more shift works in a month were more likely to demonstrate DEBQ scores of abnormal emotional (adjusted odds ratio (aOR) 2.91\%, 95\% C.I 1.57-5.42, $p=0.001$ ) and restraint (aOR 3.35, 95\% C.I $1.76-6.38, p<0.001$ ) [95]. Another study on chrononutrition emphasized that those who were having more erratic meal routine had higher risk of developing obesity and metabolic syndrome, 
despite using less energy than those who had regular meal patterns [58]. Other studies showed lower quality of diet in shift workers, such as greater consumption of sugar [96], saturated fat $[97,98]$, and sweetened beverages [96,99], and poorer intake of vegetables [98,100]. Moreover, hyperphagia, obesity, and insulin resistance were seen in view of circadian rhythm misalignment [101-103]. This was because of the regulation of circadian expression and activity of enzymes and hormones engaged in metabolism, which was altered due to the disruption in the clock regulation in the brain and peripheral tissues [26,104,105].

Strickland et al. (2015) reported that the duration of time breaks during working late shifts has a significant effect on the healthy eating among shift workers. Time restriction impedes consumption of healthy food, reduces satiety, and increases binge eating [106]. The prevalence of eating disorder was also found to be higher among shift workers with extreme job stress, reflecting that there was inter-related relationship between psychosocial well-being and nutritional intake [107]. Similarly, an earlier study demonstrated an unusual pattern of restrained or binge eating among shift workers who struggled with high stress [108].

Researchers also suggested that working in shift schedules alters not only the usual meal timing, but also the accessibility of healthy meals, hence, giving rise to multiple health-related problems [96,109]. Shift workers who work during night shifts are likely to consume fast food and processed food with high content of sugar or salt from prepackaged meals or vending machines, due to less availability of food services [6]. Night shift workers frequently experience decreased stamina and sleepiness at work, and while this may be linked to the high content of sugar and the availability of food, it is largely due to the circadian influence of sleep pressure that is greatest at night [110].

Furthermore, there was a considerably larger proportion of energy from sugar consumed over a $24 \mathrm{~h}$ period with night shift workers compared with day shift workers [111]. De Assis et al. (2003) found that there was no significant difference in total food consumption between morning, afternoon, and night shift workers. Nevertheless, it was reported that morning shift workers consumed more energy and macronutrients in the morning than the other shift workers. In comparison to the morning shift workers, the afternoon and night shift workers had a higher energy consumption at noon and at dawn, respectively. Meanwhile, throughout their work shifts, night shift workers and morning shift workers ingested high-energy foods and drinks, compared with afternoon shift workers. It can be established that while total energy consumption and composition are less influenced by changes in shift work over a $24 \mathrm{~h}$ span, the frequency of meals was reduced and the prevalence of high-energy snacking during the specific shift worked was increased [96].

Figure 2 illustrates the regulation of hormones that synchronically regulate metabolism based on the biological clock [112].

Chronobiologically, late-night meals and sleeping during the day disrupt the regulation system and affect the individual's appetite as well as metabolism. Furthermore, during daytime, humans are predisposed to the promotion of glucose metabolism and fat storage when they normally eat, meanwhile, at night, they are predisposed to glucose sparing and fat metabolism when they normally fast. Due to this predisposition, shift workers present a lowered glucose and lipid tolerance consecutively because of the change from day to night duties [113].

A study by Bandin et al. (2015) examined the influence of meal timing changes on the energy expenditure, glucose tolerance, and circadian-related variables, in which the participants were provided with standardized meals during the two meal intervention weeks and were observed under two lunch eating conditions: early eating (lunch at 13:00) and late eating (lunch at 16:30). It was found that eating late was associated with decreased resting energy expenditure, decreased fasting carbohydrate oxidation, decreased glucose tolerance, blunted daily profile in free cortisol concentrations, and decreased thermal effect on food. It also emphasized the implications on the differential effects of meal timing on metabolic health in this study [54]. 


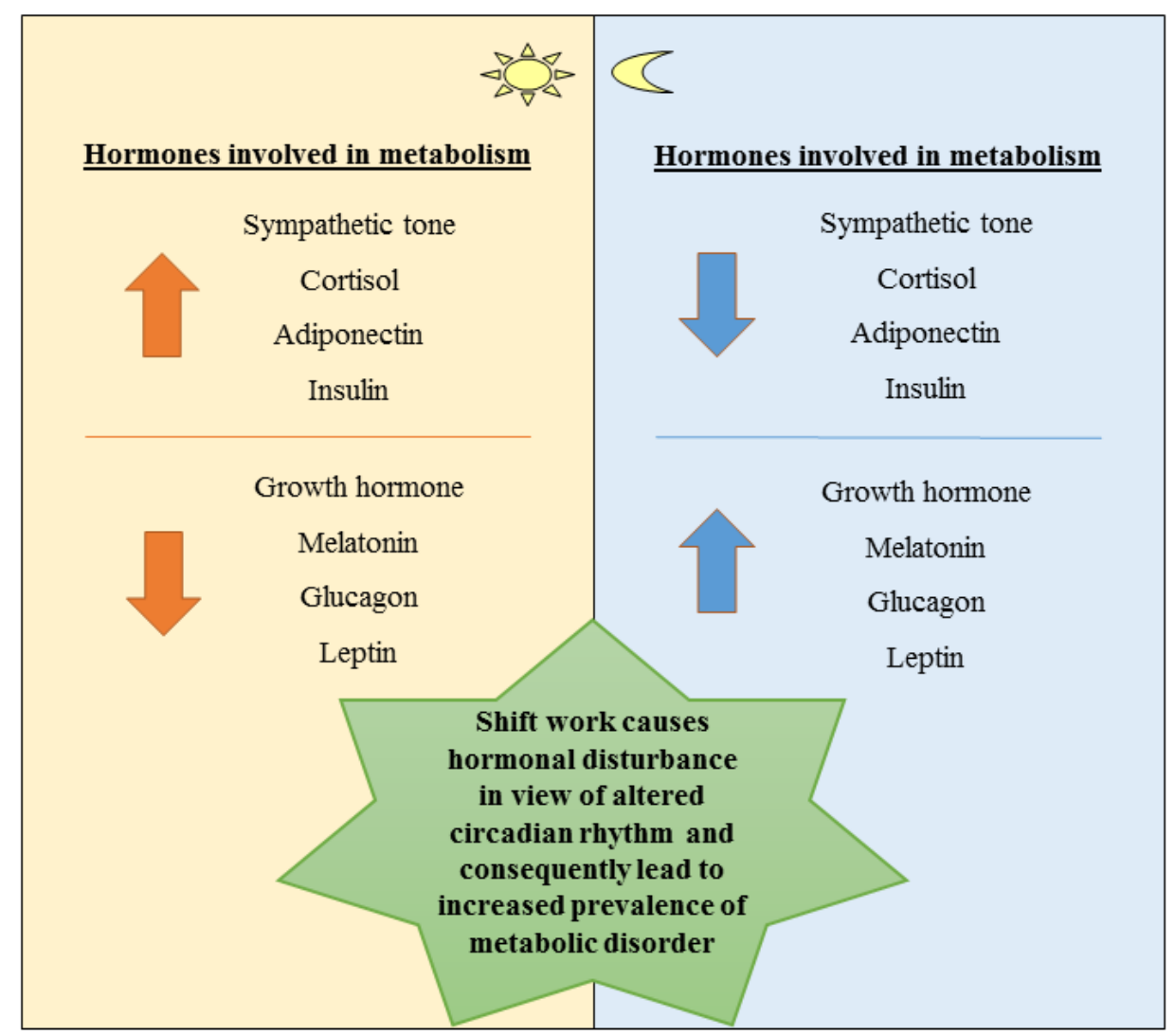

Figure 2. Schematic diagram showing effect of different hormones based on circadian rhythm. Adapted from Bass et al. (2010) [112].

\subsection{Altered Sleep/Wake Cycle and Nutritional Intake}

Baron et al. (2011) and Hsieh et al. (2011) identified that there was an association between short sleep duration of less than $5 \mathrm{~h}$ or late sleepers (midpoint of sleep > 5:30 am) and eating late-night meals or consuming more calories late in the evening with significantly greater risk for having obesity and diabetes [53,114]. In addition to that, a study by Colles et al. (2007) also demonstrated that night eating syndrome characterized by a time-delayed eating pattern was strongly related to increased body mass index (BMI) [115].

Meal timing has an important impact on circadian rhythm in peripheral organs, causing feeding time and circadian clocks to be tightly intertwined [116]. Feeding-fasting cycles are generated by time-restricted feeding which consolidate circadian rhythmicity in gene expression and numerous metabolic pathways' circadian activation. This is because the clock in a majority of the peripheral organs readily responds to feeding cycles, and feeding time can shift their period. Upon a few days of time-restricted feeding, the availability of food and the endogenous clocks are coordinated, irrespectively of whether the meal is served in the light or dark phase. Thus, diet which contains high fat alters circadian rhythmicity through dampening of feeding-fasting cycles [117].

\subsection{Psychosocial Well-Being and Nature of Work}

Working conditions play an increasingly authoritative role in psychological and mental well-being among changing social circumstances. Due to its nature, psychosocial work conditions could not be characterized by direct measurements in comparison with physical or chemical hazards [118]. Psychosocial factors include aspects like social support in the workplace, job satisfaction, or physical workload [119]. Another study by Goetz et al. (2015) found that there were a variety of psychosocial factors which correlated with burnout, such as symptoms of higher cognitive stress, conflicts between 
job and privacy, emotional demands and role-conflict, lower general health, satisfaction with life, demands to conceal emotions, and younger practical assistants [120].

Shift workers involved in night shifts reported more psychological and mental health issues than day workers. The problems comprise irritability, somatization, obsessive-compulsive disorder, interpersonal sensitivity, anxiety, altered mood, and paranoid disorders that had more prevalence predominantly [121]. Besides, other studies also showed the average sleep quality among night shift workers to be relatively lower compared with day and no night rotating workers [122,123]. These data highlight that working in shifts especially in night schedule has negative effects on psychological and social well-being [124].

\subsection{Relationship of Nutritional Intake and Psychosocial Well-Being among Shift Workers}

Based on a recent scoping review by Gupta et al. (2019), the emotional state resulting from a night shift is reported to have an effect on food consumption, not just on-shift but on the day after [44]. Shift workers may cope with the stress associated with work by consuming more food than usual, such as increased consumption of junk foods $[125,126]$. Junk foods are known as energy-, fat-, sugar-, and/or sodium-dense foods [127], but deprived of vitamins and micronutrients [128]. These are low-quality food choices, also called calorie-dense food, which is nutritionally poor and contains many more calories than nutrients like vitamins and minerals [129]. Earlier studies suggested that with the contrast of high-fat with high-carbohydrate meals, major postprandial effects of diet, or interactions with time of day, a variety of mood states, including alertness, boredom and mental slowing, were observed [130].

Stress eating is a common phenomenon [131], and shift work is linked to high rates of work stress [132]. In this sense, eating on shift, while bad for long-term health, may be important for coping on shift. Shift workers usually report having irritability, nervousness, and anxiety in association with stressful working conditions as well as hardships in family and social life. Continuous circadian rhythm disruption and sleep deprivation may complicate with chronic fatigue, mood disorders, neuroticism, chronic anxiety, or depression, subsequently leading the workers to have higher absenteeism and frequently need the administration of psychotropic drugs like sedatives and hypnotics [133].

Moreover, there is a syndrome known as "shift work disorder" that has been proposed recently, and it is characterized by the presence of the following symptoms: disrupted circadian rhythm of sleep/wake, insomnia, fatigue, and excessive day sleepiness [134,135]. Daily levels of alertness and job performance are altered by the night shift duties as they induce sleep deprivation $[136,137]$. There are also negative impacts on the quality of life among the shift workers, as seen with greater divorce and suicidal rates, poor morale, higher usage of alcohol and drugs, and a sense of malaise provoked by the deficiency of pleasure in the domestic as well as social areas of life [138].

Ferri et al. (2016) highlighted that nurses with rotating night duties require specific consideration because of greater risk for job dissatisfaction and negative health outcomes. This cross-sectional study investigated the comparison between nurses with night shifts and nurses with day shifts, with the association of risk factors predisposing nurses to worse health effects and lower job satisfaction. The results showed a statistically significant association in the nurses engaged with rotating night duties, where they reported the lowest mean score in the items of job satisfaction, quality and quantity of sleep, with more frequent chronic fatigue, psychological and cardiovascular symptoms as compared with the day shift workers [24]. Depressive symptoms were more frequently related to night eating syndrome [139-141]. However, it may be affected by the concurrence of binge eating disorder, which is highly associated with psychological distress [142]. In addition, there is a link between binge eating disorder and night eating syndrome $[143,144]$ as well as nocturnal snacking $[145,146]$ in obese population, but the description of the relationship still remains unclear.

Increased intake of snacks and fast food among shift workers results in high intake of energy-dense and high-fat diet. In an earlier study conducted by researchers from Arizona university, it was found that $60 \%$ of individuals admitted to night-time snacking and lack of adequate sleep, which led to craving for more junk food [147]. The researchers held the view that inadequate sleep, junk food consumption, 
and unhealthy night-time snacking represented the fact that sleep helps regulate metabolism [147]. Sleep may give the individual a better feeling of overcoming stress and somehow protect from unhealthy eating. When food is taken late at night, the body may not be able to burn enough calories, and they may be stored. Unless there is an activity at night, all consumed food may cause harmful effects. Sedentary jobs such as working at any call center or any office where movement is minimal mean there is more likelihood of food being digested at a different rate. Diurnal and nocturnal variation is also hormone- and temperature-related, and it may influence the metabolism in any individual.

The fatigue in shift workers may explain the reluctance for them to prepare healthy meals, alternatively substituting with industrial snacks, fast food, and sweets [148]. Table 2 describes the prevalence of overweight and obesity among shift workers. Hence, the prevalence indicates that there is an urgency to have nutritionists/dietitians in the $24 \mathrm{~h}$ industries that specifically look into the well-being of the shift workers on their nutritional status.

Table 2. Prevalence of overweight and obesity in workers from different parts of the world.

\begin{tabular}{|c|c|c|c|c|c|}
\hline Study \& Country & Sampling Frame & Method & $\begin{array}{l}\text { Sample } \\
\text { Size }(n)\end{array}$ & Criteria Used & $\begin{array}{c}\text { Prevalence of } \\
\text { Overweight/Obesity }\end{array}$ \\
\hline $\begin{array}{l}\text { Zhao et al. [149] } \\
\text { (Australia) }\end{array}$ & Nurses and midwives & $\begin{array}{c}\text { Cross-sectional } \\
\text { study }\end{array}$ & 1235 & WHO & $\begin{array}{l}32.9 \% \text { overweight; } \\
27.4 \% \text { obesity }\end{array}$ \\
\hline $\begin{array}{c}\text { Canuto et al. [150] } \\
\text { (Brazil) }\end{array}$ & $\begin{array}{c}\text { Shift workers in } \\
\text { poultry-processing plant }\end{array}$ & $\begin{array}{c}\text { Cross-sectional } \\
\text { study }\end{array}$ & 580 & $\mathrm{WHO}$ & $11.2 \%$ obesity \\
\hline $\begin{array}{l}\text { Kubo et al. [151] } \\
\text { (Japan) }\end{array}$ & $\begin{array}{l}\text { Shift workers } \\
\text { manufacturing } \\
\text { industry-based } \\
\text { corporation }\end{array}$ & $\begin{array}{l}\text { Retrospective } \\
\text { cohort study }\end{array}$ & 920 & $\begin{array}{c}\text { Obesity }(\mathrm{BMI} \geq \\
\left.25.0 \mathrm{~kg} / \mathrm{m}^{2}\right)\end{array}$ & $21.1 \%$ obesity \\
\hline $\begin{array}{l}\text { Whitfield et al. [152] } \\
\text { (United States) }\end{array}$ & Long-haul truck drivers & $\begin{array}{c}\text { Cross-sectional } \\
\text { study }\end{array}$ & 92 & $\mathrm{WHO}$ & $\begin{array}{c}86 \% \text { overweight; } 66 \% \\
\text { obesity }\end{array}$ \\
\hline $\begin{array}{l}\text { Guo et al. [153] } \\
\text { (China) }\end{array}$ & $\begin{array}{l}\text { Shift workers in motor } \\
\text { corporation }\end{array}$ & $\begin{array}{l}\text { Cross-sectional } \\
\text { study with } \\
\text { retrospective } \\
\text { assessment }\end{array}$ & 9088 & $\begin{array}{c}\text { Obesity }(\mathrm{BMI} \geq \\
\left.28.0 \mathrm{~kg} / \mathrm{m}^{2}\right)\end{array}$ & $13.5 \%$ obesity \\
\hline
\end{tabular}

Note: WHO, World Health Organization with BMI (body mass index) cut-offs for underweight $\left(\mathrm{BMI}<18.5 \mathrm{~kg} / \mathrm{m}^{2}\right.$ ), normal (BMI 18.5 to $24.9 \mathrm{~kg} / \mathrm{m}^{2}$ ), overweight (BMI 25.0 to $29.9 \mathrm{~kg} / \mathrm{m}^{2}$ ), and obesity (BMI $\geq 30.0 \mathrm{~kg} / \mathrm{m}^{2}$ ).

\section{Conclusions}

In a nutshell, the nutritional intake and psychosocial well-being in shift workers need further attention. This is due to the occurrence of circadian rhythm misalignment when the individual works in the shift duties, subsequently causing the meal timing to be interrupted. However, it is not relevant to get rid of the shift work system in society in view of the expanding twenty-four-hour industry, globally. Shift workers need to assure the operation of $24 \mathrm{~h}$ basis to take place smoothly. Thus, proper meal intervention for the shift workers has to be emphasized in terms of the type of food to be consumed during shift duties, the timing of meal to be taken, as well as how to have a healthy diet. Further studies are recommended to promote good nutritional intake and psychosocial well-being among shift workers in our society.

Author Contributions: Conceptualization of main idea of manuscript and in charge of overall direction, N.J.; writing —original draft preparation and editing, N.A.S.M.A.; supervision and provide critical feedback, N.I.M.F.T., S.A., S.D., N.E. All authors have read and agreed to the published version of the manuscript.

Funding: This work was supported by the Universiti Sains Islam Malaysia Grant, grant number USIM/FRGS/FPSK/055002/50419, FRGS/1/2019/SS05/USIM/02/3.

Acknowledgments: We wish to acknowledge the authors in this review and the collaborating universities.

Conflicts of Interest: The authors declare no conflict of interest. The funders had no role in the design of the study; in the collection, analyses, or interpretation of data; in the writing of the manuscript, or in the decision to publish the results. 


\section{References}

1. Åkerstedt, T. Psychological and psychophysiological effects of shift work. Scand. J. Work. Environ. Health 1990, 16, 67-73. [CrossRef]

2. De C Moreno, C.R.; Fischer, F.M.; Rotenberg, L. Worker's health in society 24 h. São Paulo Em Perspect 2003, $17,34-46$.

3. Ruddick-Collins, L.C.; Johnston, J.D.; Morgan, P.J.; Johnstone, A.M. The Big Breakfast Study: Chrono-nutrition influence on energy expenditure and bodyweight. Nutr. Bull. 2018, 43, 174-183. [PubMed]

4. Kawabe, Y.; Nakamura, Y.; Kikuchi, S.; Murakami, Y.; Tanaka, T.; Takebayashi, T.; Okayama, A.; Miura, K.; Okamura, T.; Ueshima, H.; et al. Relationship Between Shift Work and Clustering of the Metabolic Syndrome Diagnostic Components. J. Atheroscler. Thromb. 2014, 21, 703-711. [CrossRef] [PubMed]

5. Lowden, A.; Moreno, C.; Holmback, U.; Lennernas, M.; Tucker, P. Eating and shift work—Effects on habits, metabolism, and performance. Scand. J. Work Environ. Health 2010, 36, 150-162. [CrossRef] [PubMed]

6. Waterhouse, J.; Buckley, P.; Edwards, B.; Reilly, T. Measurement of, and some reasons for, differences in eating habits between night and day workers. Chronobio. Int. 2003, 20, 1075-1092.

7. Waterhouse, J.; Minors, D.; Atkinson, G.; Benton, D. Chronobiology and meal times: Internal and external factors. Br. J. Nutr. 1997, 77, S29-S38.

8. Antunes, L.; Levandovski, R.; Dantas, G.; Caumo, W.; Hidalgo, M.P. Obesity and shift work: Chronobiological aspects. Nutr. Res. Rev. 2010, 23, 155-168.

9. Gibson, E.L.; Green, M.W. Nutritional influences on cognitive function: Mechanisms of susceptibility. Nutr. Res. Rev. 2002, 15, 169-206.

10. Dye, L.; Lluch, A.; Blundell, J.E. Macronutrients and mental performance. Nutrition 2000, 16, $1021-1034$. [CrossRef]

11. Kanarek, R. Psychological effects of snacks and altered meal frequency. Br. J. Nutr. 1997, 77, S105-S120. [PubMed]

12. The Japan Institute for Labour Policy and Training. 2012. Tokyo: c2003-2013. Available online: http: //www.jil.go.jp/kokunai/statistics/databook/2012/06/p195-202_t6-6.pdf (accessed on 13 November 2019).

13. Nielsen, N.R.; Stahlberg, C.; Strandberg-Larsen, K.; Kristensen, T.S.; Zhang, Z.-F.; Hundrup, Y.A.; Grønbæk, M. Are work-related stressors associated with diagnosis of more advanced stages of incident breast cancers? Cancer Causes Control 2007, 19, 297-303. [PubMed]

14. ASEAN Briefing. Labour Contracts in ASEAN. 2019. Available online: https://www.aseanbriefing.com/ news/2019/03/21/labor-contracts-asean.html (accessed on 26 November 2019).

15. Wang, X.-S.; Armstrong, M.E.G.; Cairns, B.; Key, T.J.; Travis, R.C. Shift work and chronic disease: The epidemiological evidence. Occup. Med. 2011, 61, 78-89.

16. Faraut, B.; Bayon, V.; Leger, D. Neuroendocrine, immune and oxidative stress in shift workers. Sleep Med. Rev. 2013, 17, 433-444. [PubMed]

17. International Labour Organization. C171-Night Work Convention. Genebra, 1990. Available online: http://www.ilo.org/dyn/normlex/en/f?p=NORMLEXPUB:12100:0::NO::P12100_ILO_CODE:C171 (accessed on 26 November 2019).

18. Harrington, J.M. Health effects of shift work and extended hours of work. Occup. Environ. Med. 2001, 58, 68-72. [CrossRef]

19. World Health Organization. Basic Documents, 39th ed.; WHO: Geneva, Switzerland, 1992.

20. Atkinson, G.; Fullick, S.; Grindey, C.; MacLaren, D.; Waterhouse, J. Exercise, Energy Balance and the Shift Worker. Sports Med. 2008, 38, 671-685.

21. Burch, J.B.; Yost, M.G.; Johnson, W.; Allen, E. Melatonin, Sleep, and Shift Work Adaptation. J. Occup. Environ. Med. 2005, 47, 893-901.

22. Thomas, C.; Power, C.; Slimings, C. Shift work and risk factors for cardiovascular disease: A study at age 45 years in the 1958 British birth cohort. Eur. J. Epidemiol. 2010, 25, 305-314.

23. Wright, K.P., Jr.; McHill, A.W.; Birks, B.R.; Griffin, B.R.; Rusterholz, T.; Chinoy, E.D. Entrainment of the human circadian clock to the natural light-dark cycle. Curr. Boil. 2013, 23, 1554-1558.

24. Ferri, P.; Guadi, M.; Marcheselli, L.; Balduzzi, S.; Magnani, D.; Di Lorenzo, R. The impact of shift work on the psychological and physical health of nurses in a general hospital: A comparison between rotating night shifts and day shifts. Risk Manag. Health Policy 2016, 9, 203-211. 
25. Van Cauter, E.; Aschoff, J. Endocrine and other biological rhythms. In DeGroot L. Endocrinology, 2nd ed.; Saunders: Philadelphia, PA, USA, 1989; pp. 2658-2705.

26. Froy, O. Metabolism and Circadian Rhythms-Implications for Obesity. Endocr. Rev. 2009, 31, 1-24. [CrossRef] [PubMed]

27. Gifkins, J.; Johnston, A.N.; Loudoun, R. The impact of shift work on eating patterns and self-care strategies utilised by experienced and inexperienced nurses. Chronobiol Int. 2018, 35, 811-820. [CrossRef]

28. Al-Naimi, S.; Hampton, S.M.; Richard, P.; Tzung, C.; Morgan, L.M. Postprandial metabolic profiles following meals and snacks eaten during simulated night and day shift work. Chronobiol Int. 2004, 21, 937-947. [CrossRef] [PubMed]

29. Czeisler, C.A.; Johnson, M.P.; Duffy, J.F.; Brown, E.N.; Ronda, J.M.; Kronauer, R.E. Exposure to Bright Light and Darkness to Treat Physiologic Maladaptation to Night Work. New Engl. J. Med. 1990, 322, 1253-1259. [CrossRef] [PubMed]

30. McHill, A.W.; Wright, K.P., Jr. Role of sleep and circadian disruption on energy expenditure and in metabolic predisposition to human obesity and metabolic disease. Obes. Rev. 2017, 18, 15-24. [CrossRef] [PubMed]

31. Mohawk, J.A.; Green, C.B.; Takahashi, J.S. Central and peripheral circadian clocks in mammals. Annu. Rev. Neurosci. 2012, 35, 445-462. [CrossRef]

32. Teclemariam-Mesbah, R.; Ter Horst, G.J.; Postema, F.; Wortel, J.; Buijs, R.M. Anatomical demonstration of the suprachiasmatic nucleus-pineal pathway. J. Comp. Neurol. 1999, 406, 171-182. [CrossRef]

33. Ohdo, S. Chronotherapeutic strategy: Rhythm monitoring, manipulation and disruption. Adv. Drug Deliv. Rev. 2010, 62, 859-875. [CrossRef]

34. Stokkan, K.-A. Entrainment of the Circadian Clock in the Liver by Feeding. Science 2001, 291, 490-493. [CrossRef]

35. Arble, D.; Bass, J.; Laposky, A.D.; Vitaterna, M.H.; Turek, F.W. Circadian Timing of Food Intake Contributes to Weight Gain. Obes. 2009, 17, 2100-2102. [CrossRef]

36. Houghton, M. The American Heritage Medical Dictionary; Houghton Mifflin Company: Boston, MA, USA, 2004.

37. National Sleep Foundation. What Happens When You Sleep? 2011. Available online: http://www. sleepfoundation.org/article/how-sleep-works/what-happens-when-you-sleep (accessed on 17 November 2019).

38. Learthart, S. Health effects of internal rotation of shifts. Nurs. Stand. 2000, 14, 34-36. [CrossRef] [PubMed]

39. Heath, G.; Roach, G.D.; Dorrian, J.; Ferguson, S.A.; Darwent, D.; Sargent, C. The effect of sleep restriction on snacking behaviour during a week of simulated shiftwork. Accid. Anal. Prev. 2012, 45, 62-67. [CrossRef] [PubMed]

40. Åkerstedt, T. Shift work and disturbed sleep/wakefulness. Occup. Med. 2003, 53, 89-94. [CrossRef] [PubMed]

41. Shao, M.-F.; Chou, Y.-C.; Yeh, M.-Y.; Tzeng, W.-C. Sleep quality and quality of life in female shift-working nurses. J. Adv. Nurs. 2010, 66, 1565-1572. [CrossRef]

42. Spiegel, K.; Tasali, E.; Penev, P.; Van Cauter, E. Brief communication: Sleep curtailment in healthy young men is associated with decreased leptin levels, elevated ghrelin levels, and increased hunger and appetite. Ann. Intern. Med. 2004, 141, 846-850. [CrossRef]

43. Gangwisch, J.; Malaspina, L.; Boden-Albala, B.; Heymsfield, S.B. Inadequate sleep as a risk factor for obesity: Analyses of the NHANES I. Sleep 2005, 28, 1289-1296. [CrossRef]

44. Gupta, C.C.; Coates, A.; Dorrian, J.; Banks, S. The factors influencing the eating behaviour of shiftworkers: What, when, where and why. Ind. Health 2018, 57, 419-453. [CrossRef]

45. Persson, M.; Martensson, J. Situations influencing habits in diet and exercise among nurses working night shift. J. Nurs. Manag. 2006, 14, 414-423. [CrossRef]

46. Czeisler, C.A.; Buxton, O.M.; Khalsa, S.B. The human circadian timing system and sleep-wake regulation. In Principles and Practice of Sleep Medicine; Kryger, M., Roth, T., Dement, W.C., Eds.; Elsevier: Philadelphia, PA, USA, 2005.

47. Duffy, J.F.; Wright, K.P. Entrainment of the Human Circadian System by Light. J. Boil. Rhythm. 2005, 20, 326-338. [CrossRef]

48. Boivin, D.B.; Tremblay, G.M.; James, F.O. Working on atypical schedules. Sleep Med. 2007, 8, 578-589. [CrossRef] 
49. Axelsson, J.; Akerstedt, T.; Kecklund, G.; Lowden, A. Tolerance to shift work-how does it relate to sleep and wakefulness? Int. Arch. Occup. Environ. Health 2004, 77, 121-129. [CrossRef] [PubMed]

50. Folkard, S. Do Permanent Night Workers Show Circadian Adjustment? A Review Based on the Endogenous Melatonin Rhythm. Chonobiol. Int. 2008, 25, 215-224. [CrossRef] [PubMed]

51. Morris, C.J.; Yang, J.N.; Garcia, J.I.; Myers, S.; Bozzi, I.; Wang, W.; Buxton, O.M.; Shea, S.A.; Scheer, F.A.J.L. Endogenous circadian system and circadian misalignment impact glucose tolerance via separate mechanisms in humans. Proc. Natl. Acad. Sci. USA 2015, 112, E2225-E2234. [CrossRef] [PubMed]

52. Morris, C.J.; Purvis, T.E.; Mistretta, J.; Scheer, F.A. Effects of the Internal Circadian System and Circadian Misalignment on Glucose Tolerance in Chronic Shift Workers. J. Clin. Endocrinol. Metab. 2016, 101, 1066-1074. [CrossRef] [PubMed]

53. Baron, K.G.; Reid, K.; Kern-Goldberger, A.; Zee, P.C. Role of Sleep Timing in Caloric Intake and BMI. Obesity 2011, 19, 1374-1381. [CrossRef]

54. Bandín, C.; Scheer, F.A.J.L.; Luque, A.J.; Àvila-Gandía, V.; Zamora, S.; Madrid, J.A.; Gómez-Abellán, P.; Garaulet, M. Meal timing affects glucose tolerance, substrate oxidation and circadian-related variables: A randomized, crossover trial. Int. J. Obes. 2014, 39, 828-833. [CrossRef]

55. Nikpour, M.; Tirgar, A.; Hajiahmadi, M.; Hosseini, A.; Heidari, B.; Ghaffari, F.; Ebadi, A.; Nasiri, F.; Firouzbakht, M. Shift work and metabolic syndrome: A multi-center cross-sectional study on females of reproductive age. Biomed. Rep. 2019, 10,311-317.

56. Koh, S.J.; Kim, M.; Oh, D.Y.; Kim, B.G.; Lee, K.L.; Kim, J.W. Psychosocial Stress in Nurses With Shift Work Schedule Is Associated With Functional Gastrointestinal Disorders. J. Neurogastroenterol. Motil 2014, 20, 516-522. [CrossRef]

57. Knutsson, A.; Alfredsson, L.; Karlsson, B.; Åkerstedt, T.; Fransson, E.; Westerholm, P.; Westerlund, H. Breast cancer among shift workers: Results of the WOLF longitudinal cohort study. Scand. J. Work. Environ. Health 2012, 39, 170-177. [CrossRef]

58. Pot, G.K.; Hardy, R.; Stephen, A.M. Irregular consumption of energy intake in meals is associated with a higher cardiometabolic risk in adults of a British birth cohort. Int. J. Obes. 2014, 38, 1518-1524. [CrossRef]

59. Pot, G.K. Sleep and dietary habits in the urban environment: The role of chrono-nutrition. Proc. Nutr. Soc. 2017, 77, 189-198. [CrossRef] [PubMed]

60. Hur, S.J.; Lim, B.O.; Decker, E.A.; McClements, D.J. In vitro human digestion models for food applications. Food Chem. 2011, 125, 1-12. [CrossRef]

61. Hellström, P.M.; Grybäck, P.; Jacobsson, H. The physiology of gastric emptying. Best Pr. Res. Clin. Anaesthesiol. 2006, 20, 397-407. [CrossRef] [PubMed]

62. Wu, T.; Sun, L.; Zhuge, F.; Guo, X.; Zhao, Z.; Tang, R.; Chen, Q.; Chen, L.; Kato, H.; Fu, Z. Differential Roles of Breakfast and Supper in Rats of a Daily Three-Meal Schedule Upon Circadian Regulation and Physiology. Chronobiol. Int. 2011, 28, 890-903. [CrossRef]

63. Loboda, A.; Kraft, W.K.; Fine, B.; Joseph, J.; Nebozhyn, M.; Zhang, C. Diurnal variation of the human adipose transcriptome and the link to metabolic disease. BMC Med. Genom. 2009, 2, 7. [CrossRef]

64. Ma, Y.; Bertone, E.R.; Stanek, E.J., 3rd; Reed, G.W.; Hébert, J.R.; Cohen, N.L.; Merriam, P.A.; Ockene, I.S. Association between eating patterns and obesity in a free-living US adult population. Am. J. Epidemiol. 2003, 158, 85-92. [CrossRef]

65. Sudo, R.O.N. Nutrient intake among female shift workers in a computer factory in Japan. Int. J. Food Sci. Nutr. 2001, 52, 367-378.

66. De Freitas, E.S.; Canuto, R.; Henn, R.L.; Olinto, B.A.; Macagnan, J.B.A.; Pattussi, M.P.; Busnello, F.M.; Olinto, M.T. Alteration in eating habits among shift workers of a poultry processing plant in Southern Brazil. Ciencia Saude Coletiva 2015, 20, 2401-2410.

67. Pollitt, E. Does Breakfast Make a Difference in School? J. Am. Diet. Assoc. 1995, 95, 1134-1139. [CrossRef]

68. Fonken, L.; Workman, J.L.; Walton, J.C.; Weil, Z.; Morris, J.S.; Haim, A.; Nelson, R.J. Light at night increases body mass by shifting the time of food intake. Proc. Natl. Acad. Sci. USA 2010, 107, 18664-18669. [CrossRef]

69. Adolphus, K.; Lawton, C.; Champ, C.L.; Dye, L. The Effects of Breakfast and Breakfast Composition on Cognition in Children and Adolescents: A Systematic Review. Adv. Nutr. 2016, 7, 590S-612S. [CrossRef] [PubMed]

70. Matthys, C.; De Henauw, S.; Bellemans, M.; De Maeyer, M.; De Backer, G. Breakfast habits affect overall nutrient profiles in adolescents. Public Health Nutr. 2007, 10, 413-421. [CrossRef] [PubMed] 
71. Leidy, H.J. The Benefits of Breakfast Consumption to Combat Obesity and Diabetes in Young People. Am. J. Lifestyle Med. 2012, 7, 99-103. [CrossRef]

72. Farshchi, H.R.; Taylor, M.A.; Macdonald, I. Deleterious effects of omitting breakfast on insulin sensitivity and fasting lipid profiles in healthy lean women. Am. J. Clin. Nutr. 2005, 81, 388-396. [CrossRef] [PubMed]

73. Stote, K.S.; Baer, D.J.; Spears, K.; Paul, D.R.; Harris, G.K.; Rumpler, W.V.; Strycula, P.; Najjar, S.S.; Ferrucci, L.; Ingram, N.K.; et al. A controlled trial of reduced meal frequency without caloric restriction in healthy, normal-weight, middle-aged adults123. Am. J. Clin. Nutr. 2007, 85, 981-988. [CrossRef]

74. Cahill, L.E.; Chiuve, S.E.; Mekary, R.A.; Jensen, M.K.; Flint, A.J.; Hu, F.B.; Rimm, E.B. Prospective study of breakfast eating and incident coronary heart disease in a cohort of male US health professionals. Circulation 2013, 128, 337-343. [CrossRef]

75. Song, W.; Chun, O.K.; Obayashi, S.; Cho, S.; Chung, C.E. Is Consumption of Breakfast Associated with Body Mass Index in US Adults? J. Am. Diet. Assoc. 2005, 105, 1373-1382. [CrossRef]

76. Barr, S.I.; DiFrancesco, L.; Fulgoni, V.L. Consumption of Breakfast and the Type of Breakfast Consumed Are Positively Associated with Nutrient Intakes and Adequacy of Canadian Adults. J. Nutr. 2013, 143, 86-92. [CrossRef]

77. Nicklas, T.A.; Myers, L.; Reger, C.; Beech, B.; Berenson, G.S. Impact of Breakfast Consumption on Nutritional Adequacy of the Diets of Young Adults in Bogalusa, Louisiana. J. Am. Diet. Assoc. 1998, 98, 1432-1438. [CrossRef]

78. Leidy, H.J.; Bossingham, M.J.; Mattes, R.; Campbell, W. Increased dietary protein consumed at breakfast leads to an initial and sustained feeling of fullness during energy restriction compared to other meal times. Br. J. Nutr. 2009, 101, 798-803. [CrossRef]

79. Leidy, H.J.; Racki, E.M. The addition of a protein-rich breakfast and its effects on acute appetite control and food intake in 'breakfast-skipping' adolescents. Int. J. Obes. 2010, 34, 1125-1133. [CrossRef] [PubMed]

80. Jakubowicz, D.; Froy, O.; Wainstein, J.; Boaz, M. Meal timing and composition influence ghrelin levels, appetite scores and weight loss maintenance in overweight and obese adults. Steroids 2012, 77, 323-331. [CrossRef] [PubMed]

81. Almoosawi, S.; Prynne, C.J.; Hardy, R.; Stephen, A.M. Time-of-day and nutrient composition of eating occasions: Prospective association with the metabolic syndrome in the 1946 British birth cohort. Int. J. Obes. 2012, 37, 725-731. [CrossRef] [PubMed]

82. Haus, E.; Reinberg, A.; Mauvieux, B.; Le Floc'H, N.; Sackett-Lundeen, L.; Touitou, Y. Risk of obesity in male shift workers: A chronophysiological approach. Chronobiol. Int. 2016, 33, 1018-1036. [CrossRef]

83. St-Onge, M.-P.; Ard, J.; Baskin, M.L.; Chiuve, S.E.; Johnson, H.M.; Kris-Etherton, P.; Varady, K. Meal Timing and Frequency: Implications for Cardiovascular Disease Prevention: A Scientific Statement From the American Heart Association. Circulation 2017, 135, e96-e121. [CrossRef]

84. Berg, C.; Lappas, G.; Wolk, A.; Strandhagen, E.; Torén, K.; Rosengren, A.; Thelle, D.; Lissner, L. Eating patterns and portion size associated with obesity in a Swedish population. Appetite 2009, 52, 21-26. [CrossRef]

85. Cleator, J.; Abbott, J.; Judd, P.; Sutton, C.; Wilding, J.P. Night eating syndrome: Implications for severe obesity. Nutr. Diabetes 2012, 2, e44. [CrossRef]

86. Striegel-Moore, R.H.; Rosselli, F.; Wilson, G.T.; Perrin, N.; Harvey, K.; DeBar, L. Nocturnal eating: Association with binge eating, obesity, and psychological distress. Int. J. Eat. Disord. 2010, 43, 520-526. [CrossRef]

87. Paz, A.; Berry, E.M. Effect of meal composition on alertness and performance of hospital night-shift workers. Ann. Nutr. Metab. 1997, 41, 291-298. [CrossRef]

88. Johnston, C.S.; Day, C.S.; Swan, P.D. Postprandial Thermogenesis Is Increased 100\% on a High-Protein, Low-Fat Dietversusa High-Carbohydrate, Low-Fat Diet in Healthy, Young Women. J. Am. Coll. Nutr. 2002, 21, 55-61. [CrossRef]

89. Nehme, P.; Marqueze, E.C.; Ulhôa, M.; Moulatlet, E.; Codarin, M.A.; Moreno, C.R.C. Effects of a carbohydrate-enriched night meal on sleepiness and sleep duration in night workers: A double-blind intervention. Chronobiol. Int. 2014, 31, 453-460. [CrossRef]

90. Bonham, M.; Bonnell, E.K.; Huggins, C.E. Energy intake of shift workers compared to fixed day workers: A systematic review and meta-analysis. Chronobiol. Int. 2016, 33, 1086-1100. [CrossRef] [PubMed]

91. Moran-Ramos, S.; Baez-Ruiz, A.; Buijs, R.M.; Escobar, C. When to eat? The influence of circadian rhythms on metabolic health: Are animal studies providing the evidence? Nutr. Res. Rev. 2016, 29, 180-193. [CrossRef] [PubMed] 
92. Strzemecka, J.; Bojar, I.; Strzemecka, E.; Owoc, A. Dietary habits among persons hired on shift work. Ann. Agric. Environ. Med. 2014, 21, 128-131. [PubMed]

93. Nyberg, M.; Wiklund, M. Impossible meals? The food and meal situation of flight attendants in Scandinavia-A qualitative interview study. Appetite 2017, 113, 162-171. [CrossRef]

94. Jack, F.R.; Piacentini, M.; Schröder, M.J. Perception and Role of Fruit in the Workday Diets of Scottish Lorry Drivers. Appetite 1998, 30, 139-149. [CrossRef]

95. Wong, H.; Wong, M.C.; Wong, S.Y.; Lee, A. The association between shift duty and abnormal eating behaviour among nurses working in a major hospital: A cross-sectional study. Int. J. Nurs. Stud. 2010, 47, 1021-1027. [CrossRef]

96. De Assis, M.A.; Kupek, E.; Nahas, M.V.; Bellisle, F. Food intake and circadian rhythms in shift workers with a high workload. Appetite 2003, 40, 175-183. [CrossRef]

97. Esquirol, Y.; Perret, B.; Ruidavets, J.-B.; Marquie, J.-C.; Dienne, E.; Niezborala, M.; Ferrières, J. Shift work and cardiovascular risk factors: New knowledge from the past decade. Arch. Cardiovasc. Dis. 2011, 104, 636-668. [CrossRef]

98. Hemiö, K.; Puttonen, S.; Viitasalo, K.; Härmä, M.; Peltonen, M.; Lindstrom, J. Food and nutrient intake among workers with different shift systems. Occup. Environ. Med. 2015, 72, 513-520. [CrossRef]

99. Tada, Y.; Kawano, Y.; Maeda, I.; Yoshizaki, T.; Sunami, A.; Yokoyama, Y.; Matsumoto, H.; Hida, A.; Komatsu, T.; Togo, F. Association of body mass index with lifestyle and rotating shift work in Japanese female nurses. Obesity 2014, 22, 2489-2493. [CrossRef]

100. Balieiro, L.C.T.; Rossato, L.; Waterhouse, J.; Paim, S.L.; Mota, M.C.; Crispim, C.A. Nutritional status and eating habits of bus drivers during the day and night. Chronobiol. Int. 2014, 31, 1123-1129. [CrossRef]

101. Turek, F.W.; Joshu, C.; Kohsaka, A.; Lin, E.; Ivanova, G.; McDearmon, E.; Laposky, A.; Losee-Olson, S.; Easton, A.; Jensen, D.R.; et al. Obesity and Metabolic Syndrome in Circadian Clock Mutant Mice. Science 2005, 308, 1043-1045. [CrossRef]

102. Barnea, M.; Madar, Z.; Froy, O. High-Fat Diet Delays and Fasting Advances the Circadian Expression of Adiponectin Signaling Components in Mouse Liver. Endocrinology 2009, 150, 161-168. [CrossRef]

103. Kohsaka, A.; Bass, J. A sense of time: How molecular clocks organize metabolism. Trends Endocrinol. Metab. 2007, 18, 4-11. [CrossRef]

104. Panda, S.; Antoch, M.P.; Miller, B.H.; Su, A.I.; Schook, A.B.; Straume, M.; Schultz, P.G.; Kay, S.A.; Takahashi, J.S.; HogenEsch, J.B. Coordinated transcription of key pathways in the mouse by the circadian clock. Cell 2002, 109, 307-320. [CrossRef]

105. Green, C.B.; Takahashi, J.S.; Bass, J. The Meter of Metabolism. Cell 2008, 134, 728-742. [CrossRef]

106. Strickland, J.R.; Eyler, A.A.; Purnell, J.Q.; Kinghorn, A.M.; Herrick, C.; Evanoff, B.A. Enhancing Workplace Wellness Efforts to Reduce Obesity: A Qualitative Study of Low-Wage Workers in St Louis, Missouri, 2013-2014. Prev. Chronic Dis. 2015, 12, E67. [CrossRef]

107. Allison, S. Biographic and Psychobehavioral Influences on Body Mass Index in a Nursing Sample. West. J. Nurs. Res. 2005, 27, 7-20. [CrossRef]

108. Almajwal, A.M. Stress, shift duty, and eating behaviour among nurses in Central Saudi Arabia. Saudi Med. J. 2016, 37, 191-198. [CrossRef]

109. Faugier, J.; Lancaster, J.; Pickles, D. Barriers to healthy eating in the nursing profession: Part 1 and part 2. Nurs. Stand. 2001, 15, 33-36. [PubMed]

110. Burch, J.B.; Tom, J.; Zhai, Y. Shiftwork impacts and adaptation among health care workers. Occup. Med. (Lond.) 2009, 59, 159-166. [CrossRef] [PubMed]

111. Bonnell, E.K.; Huggins, C.E.; Huggins, C.T.; McCaffrey, T.A.; Palermo, C.; Bonham, M. Influences on Dietary Choices during Day versus Night Shift in Shift Workers: A Mixed Methods Study. Nutrients 2017, 9, 193. [CrossRef]

112. Bass, J.; Takahashi, J.S. Circadian Integration of Metabolism and Energetics. Science 2010, 330, $1349-1354$. [CrossRef]

113. Habbal, O.A.; Al-Jabri, A.A. Circadian Rhythm and the Immune Response: A Review. Int. Rev. Immunol. 2009, 28, 93-108. [CrossRef]

114. Hsieh, S.D.; Muto, T.; Murase, T.; Tsuji, H.; Arase, Y. Association of short sleep duration with obesity, diabetes, fatty liver and behavioral factors in Japanese men. Intern. Med. 2011, 50, 2499-2502. [CrossRef] 
115. Colles, S.L.; Dixon, J.B.; O’Brien, P.E. Night eating syndrome and nocturnal snacking: Association with obesity, binge eating and psychological distress. Int. J. Obes. 2007, 31, 1722-1730. [CrossRef]

116. Asher, G.; Sassone-Corsi, P. Time for Food: The Intimate Interplay between Nutrition, Metabolism, and the Circadian Clock. Cell 2015, 161, 84-92. [CrossRef]

117. Eckel-Mahan, K.; Patel, V.R.; De Mateo, S.; Orozco-Solis, R.; Ceglia, N.J.; Sahar, S.; Dilag-Penilla, S.A.; Dyar, K.; Baldi, P.; Sassone-Corsi, P.; et al. Reprogramming of the circadian clock by nutritional challenge. Cell 2013, 155, 1464-1478. [CrossRef]

118. Vogel, M.; Braungardt, T.; Meyer, W.; Schneider, W. The effects of shift work on physical and mental health. J. Neural Transm. 2012, 119, 1121-1132. [CrossRef]

119. Hoogendoorn, W.E.; Van Poppel, M.N.M.; Bongers, P.M.; Koes, B.W.; Bouter, L. Systematic Review of Psychosocial Factors at Work and Private Life as Risk Factors for Back Pain. Spine 2000, 25, 2114-2125. [CrossRef] [PubMed]

120. Goetz, K.; Berger, S.; Gavartina, A.; Zaroti, S.; Szecsenyi, J. How psychosocial factors affect well-being of practice assistants at work in general medical care?-A questionnaire survey. BMC Fam. Pract. 2015, 16, 166. [CrossRef] [PubMed]

121. Shields, M. Shift work and health. Health Rep. 2002, 13, 11-33.

122. Ohida, T.; Kamal, A.; Sone, T.; Ishii, T.; Uchiyama, M.; Minowa, M.; Nozaki, S. Night-shift work related problems in young female nurses in Japan. J. Occup. Health 2001, 43, 150-156. [CrossRef]

123. Garde, A.H.; Hansen, A.M.; Hansen, J. Sleep length and quality, sleepiness and urinary melatonin among healthy Danish nurses with shift work during work and leisure time. Int. Arch. Occup. Environ. Health 2009, 82, 1219-1228. [CrossRef]

124. Selvi, Y.; Güleç, M.; Agargun, M.Y.; Besiroglu, L. Mood changes after sleep deprivation in morningness? eveningness chronotypes in healthy individuals. J. Sleep Res. 2007, 16, 241-244. [CrossRef]

125. Han, K.; Choi-Kwon, S.; Kim, K.S. Poor dietary behaviors among hospital nurses in Seoul, South Korea. Appl. Nurs. Res. 2016, 30, 38-44. [CrossRef]

126. Torquati, L.; Kolbe-Alexander, T.; Pavey, T.; Perrsson, C.; Leveritt, M. Diet and physical activity behavior in nurses: A qualitative study. Int. J. Health Promot. Educ. 2016, 54, 268-282. [CrossRef]

127. Anderson, J.W.; Patterson, K. Snack foods: Comparing nutrition values of excellent choices and "junk foods". J. Am. Coll. Nutr. 2005, 24, 155-156. [CrossRef]

128. Maillot, M.; Darmon, N.; Vieux, F.; Drewnowski, A. Low energy density and high nutritional quality are each associated with higher diet costs in French adults. Am. J. Clin. Nutr. 2007, 86, 690-696.

129. Drewnowski, A. Concept of a nutritious food: Toward a nutrient density score. Am. J. Clin. Nutr. 2005, 82, 721-732. [CrossRef]

130. Wells, A.S.; Read, N.W. Influences of fat, energy, and time of day on mood and performance. Physiol. Behav. 1996, 59, 1069-1076. [CrossRef]

131. Adam, T.C.; Epel, E. Stress, eating and the reward system. Physiol. Behav. 2007, 91, 449-458. [CrossRef]

132. Åkerstedt, T.; Knutsson, A.; Westerholm, P.; Theorell, T.; Alfredsson, L.; Kecklund, G. Sleep disturbances, work stress and work hours: A cross-sectional study. J. Psychosom. Res. 2002, 53, 741-748. [CrossRef]

133. Cole, R.J.; Loving, R.T.; Kripke, D.F. Psychiatric aspects of shift work. Occup. Med. 1990, 5, 301-314.

134. Black, J.E.; Hull, S.G.; Tiller, J.; Yang, R.; Harsh, J.R. The Long-Term Tolerability and Efficacy of Armodafinil in Patients with Excessive Sleepiness Associated with Treated Obstructive Sleep Apnea, Shift Work Disorder, or Narcolepsy: An Open-Label Extension Study. J. Clin. Sleep Med. 2010, 6, 458-466. [CrossRef]

135. Schwartz, J.R.; Khan, A.; McCall, W.V.; Weintraub, J.; Tiller, J. Tolerability and Efficacy of Armodafinil in Naïve Patients with Excessive Sleepiness Associated with Obstructive Sleep Apnea, Shift Work Disorder, or Narcolepsy: A 12-Month, Open-Label, Flexible-Dose Study with an Extension Period. J. Clin. Sleep Med. 2010, 6, 450-457. [CrossRef]

136. Boivin, D.B.; Boudreau, P. Impacts of shift work on sleep and circadian rhythms. Pathol. Boil. 2014, 62, 292-301. [CrossRef]

137. Akerstedt, T.; Wright, K.P., Jr. Sleep Loss and Fatigue in Shift Work and Shift Work Disorder. Sleep Med. Clin. 2009, 4, 257-271. [CrossRef]

138. Walker, J. Social problems of shift work. In Hours of Work-Temporal Factors in Work Scheduling; Folkard, S., Monk, T., Eds.; Wiley: New York, NY, USA, 1985; pp. 211-225. 
139. Stunkard, A.J.; Grace, W.J.; Wolff, H.G. The night-eating syndrome; a pattern of food intake among certain obese patients. Am. J. Med. 1955, 19, 78-86. [CrossRef]

140. Kuldau, J.M.; Rand, C.S.W. The night eating syndrome and bulimia in the morbidly obese. Int. J. Eat. Disord. 1986, 5, 143-148. [CrossRef]

141. Gluck, M.E.; Geliebter, A.; Satov, T. Night Eating Syndrome Is Associated with Depression, Low Self-Esteem, Reduced Daytime Hunger, and Less Weight Loss in Obese Outpatients. Obes. Res. 2001, 9, $264-267$. [CrossRef]

142. American Psychiatric Association. Diagnostic and Statistical Manual of Mental Disorders: DSM-IV, 4th ed.; American Psychiatric Association: Washington, DC, USA, 1994.

143. Adami, G.F.; Campostano, A.; Marinari, G.M.; Ravera, G.; Scopinaro, N. Night eating in obesity: A descriptive study. Nutrition 2002, 18, 587-589. [CrossRef]

144. Powers, P.S.; Perez, A.; Boyd, F.; Rosemurgy, A. Eating pathology before and after bariatric surgery: A prospective study. Int. J. Eat. Disord. 1999, 25, 293-300. [CrossRef]

145. Greeno, C.G.; Wing, R.R.; Marcus, M.D. Nocturnal eating in binge eating disorder and matched-weight controls. Int. J. Eat. Disord. 1995, 18, 343-349. [CrossRef]

146. Grilo, C.M.; Masheb, R.M. Night-time eating in men and women with binge eating disorder. Behav. Res. Ther. 2004, 42, 397-407. [CrossRef]

147. Science News. Sleep Loss Linked to Night-Time Snacking, Junk Food Cravings, Obesity, Diabetes. 2018. Available online: https://www.sciencedaily.com/releases/2018/06/180601171900.htm (accessed on 25 November 2019).

148. Bowman, S.A.; Vinyard, B.T. Fast food consumption of U.S. adults: Impact on energy and nutrient intakes and overweight status. J. Am. Coll. Nutr. 2004, 23, 163-168. [CrossRef]

149. Zhao, I.; Bogossian, F.; Song, S.; Turner, C. The Association between Shift Work and Unhealthy Weight. J. Occup. Environ. Med. 2011, 53, 153-158. [CrossRef]

150. Canuto, R.; Pattussi, M.P.; Macagnan, J.B.A.; Henn, R.L.; Olinto, M.T.A. Sleep deprivation and obesity in shift workers in southern Brazil. Public Health Nutr. 2014, 17, 2619-2623. [CrossRef]

151. Kubo, T.; Oyama, I.; Nakamura, T.; Shirane, K.; Otsuka, H.; Kunimoto, M.; Kadowaki, K.; Maruyama, T.; Otomo, H.; Fujino, Y.; et al. Retrospective cohort study of the risk of obesity among shift workers: Findings from the Industry-based Shift Workers' Health study, Japan. Occup. Environ. Med. 2010, 68, 327-331. [CrossRef]

152. Jacobson, P.J.W.; Prawitz, A.D.; Lukaszuk, J.M. Long-Haul Truck Drivers Want Healthful Meal Options at Truck-Stop Restaurants. J. Am. Diet. Assoc. 2007, 107, 2125-2129. [CrossRef] [PubMed]

153. Guo, Y.; Rong, Y.; Huang, X.; Lai, H.; Luo, X.; Zhang, Z.; Liu, Y.; He, M.; Wu, T.; Chen, W. Shift Work and the Relationship with Metabolic Syndrome in Chinese Aged Workers. PLoS ONE 2015, 10, e0120632. [CrossRef] [PubMed]

(C) 2020 by the authors. Licensee MDPI, Basel, Switzerland. This article is an open access article distributed under the terms and conditions of the Creative Commons Attribution (CC BY) license (http://creativecommons.org/licenses/by/4.0/). 